Table 1. Demographics and Clinical Characteristics of SjS patients $(n=42)$

\begin{tabular}{lc}
\hline Age (year) & $54 \pm 11$ \\
Gender (F/M) & $41 / 1$ \\
Duration of follow-up (month) & $55 \pm 51$ \\
Siccasymptoms & $39(93 \%)$ \\
Arthralgia/arthritis & $37(88 \%)$ \\
Parotitis & $9(21 \%)$ \\
RaynaudPhenomenon & $5(12 \%)$ \\
Leucocytoclasticvasculitis & $5(12 \%)$ \\
Peripheralneuropathy & $2(5 \%)$ \\
Interstitiallungdisease & $2(5 \%)$ \\
Lymphadenopathy & $6(14 \%)$ \\
ANA & $34(81 \%)$ \\
Anti-Ro/La & $19(45 \%)$ \\
\hline
\end{tabular}

Tablo-2: Disease Activity Indexes and

\begin{tabular}{|c|c|}
\hline & $n=42$ \\
\hline ESSPRI-total & $15,4 \pm 5,4$ \\
\hline -dryness & $5,7 \pm 2,2$ \\
\hline -fatigue & $5,2 \pm 2,6$ \\
\hline -pain & $5,4 \pm 2,6$ \\
\hline VAS & $55 \pm 20$ \\
\hline ESSDAI-total & $1 \pm 1$ \\
\hline Hocevar-USG Score & $20 \pm 10$ \\
\hline Milic-USG Score & $6 \pm 3$ \\
\hline
\end{tabular}

Twenty-four (57\%) and25 (60\%) patients had the cut-offvalues of $\geq 17$ (Hocevar) and $\geq 6$ (Milic USG). The patients with the scores of $\geq 17$ (Hocevar)were found to have higher scores of ESSPRI-total $(18 \pm 5$ vs $14 \pm 5, p=0,01)$. Hocevar and Milic USG scores were shown to be higher in anti-Ro(+) SjS patients ( $25 \pm 10 v s 14 \pm 7$ and $7 \pm 3 v s 4 \pm 2, p=0,01)$.USG scores were not found to be associated with the scores of ESSDAI, VAS and ESSPRI items.

Conclusions: Hocevar scoring system of major salivary glands was found to be related to patient reported activity in SjS. USG scores were associated with anti-Ro positivity. Evaluation of SG-USG might promote the diagnosis and follow-up of the SjS patients.

Disclosure of Interest: None declared

DOI: 10.1136/annrheumdis-2017-eular.6196

\section{SAT0311 PROLONGED EXPOSURE TO ANTIPHOSPHOLIPID ANTIBODIES IS ASSOCIATED WITH ENDOTHELIAL DYSFUNCTION IN PATIENTS WITH SYSTEMIC LUPUS ERYTHEMATOSUS}

Y.-J. Park ${ }^{1}$, I.-W. Baek ${ }^{2}$, K.-J. Kim ${ }^{1}$, W.-U. Kim ${ }^{3}$, C.-S. Cho ${ }^{4} .{ }^{1}$ Division of Rheumatology, St. Vincent Hospital, The Catholic University of Korea, Suwon; ${ }^{2}$ Division of Rheumatolgy, Yeouido St. Mary's Hospital, The Catholic University of Korea; ${ }^{3}$ Division of Rheumatology, Seoul St. Mary's Hospital, The Catholic University of Korea; ${ }^{4}$ Division of Rheumatology, Yeouido St. Mary's Hospital, The Catholic University of Korea, Seoul, Korea, Republic Of

Background: Antiphospholipid syndrome has been shown to be associated with increased cardiovascular mortality, but the role of antiphospholipid antibodies $(\mathrm{aPL})$ on endothelial dysfunction remains elusive.

Objectives: We investigated the association between endothelial dysfunction and aPL in systemic lupus erythematosus (SLE) patients.

Methods: 188 SLE patients and 62 controls were enrolled. Endothelial function was measured by flow-mediated dilatation (FMD). Cardiovascular risk factors were assessed and quarterly measurement of anti-cardiolipin (aCL) and anti- $\beta_{2}$ glycoprotein I Ab were used to calculate time-integrated values throughout disease duration. Circulating endothelial progenitor cell (EPC), defined by CD34+/KDR+ mononuclear cells, was quantified by flow cytometry.

Results: Median FMD was significantly lower in SLE patient than in controls (6.9 versus $9.3 \%, P<0.001)$. In univariate analysis, older age, hypertension, thrombocytopenia, and persistent positive lupus anticoagulant (LAC) were associated with decreased FMD in SLE patients $(P=0.021, P=0.011, P=0.004$, and $P=0.028)$. Time-integrated $\mathrm{aCL}$ value (TI-aCL), but not a single value, was correlated with decreased FMD $(P=0.001)$. Multivariate analysis showed that hypertension and TI-aCL were independent factors for decreased FMD ( $P=0.027$, $P=0.008$ ); addition of positive LAC increased the adjusted probability of decreased FMD $(P=0.023)$. FMD was correlated with EPC number $(\gamma=0.342, P=0.005)$ and TI-aCL was also an independent factor of reduced EPC after multiple adjustment $(P=0.019)$. The predicted probability of endothelial dysfunction at median EPC level was higher in group with high $\mathrm{TI}-\mathrm{aCL}$ than in group with low $\mathrm{Tl}-\mathrm{aCL}$ $(P=0.004)$.

Conclusions: Cumulative burden of aPL was closely associated with endothelial dysfunction in SLE patients, which was mediated in part by reduction of EPC.

Disclosure of Interest: None declared

DOI: 10.1136/annrheumdis-2017-eular.3063

\section{SATURDAY, 17 JUNE 2017 \\ Scleroderma, myositis and related syndromes - etiology, pathogenesis and animal models}

\section{SAT0312 MICRORNA-125B AS A POTENTIAL FIBROTIC AND APOPTOTIC REGULATOR IN SYSTEMIC SCLEROSIS}

A. Kozlova ${ }^{1}$, E. Pachera ${ }^{1}$, F. Renoux ${ }^{1}$, M. Rudnik ${ }^{1}$, B. Maurer ${ }^{1}$, A. Jüngel ${ }^{1}$, J.H. Distler ${ }^{2}$, G. Kania ${ }^{1}$, O. Distler ${ }^{1}$. ${ }^{1}$ Department of Rheumatology, University Hospital Zurich, Zurich, Switzerland; ${ }^{2}$ Department of Internal Medicine 3, Friedrich-Alexander University Erlangen-Nuremberg, Erlangen-Nuremberg, Germany

Background: MicroRNAs (miRs) are a class of small, noncoding RNAs that regulate many biological processes. Some microRNAs are involved in skin fibrosis.

Objectives: To analyze the differential expression, regulation and the pathophysiological role of miR-125b in systemic sclerosis (SSc).

Methods: For screening a low density array was run on pooled RNA from fibroblasts derived from 3 SSc patients vs. 3 healthy controls $(\mathrm{HC})$. For further validation we performed qPCR on RNA derived from cultured fibroblasts, whole skin biopsies as well as on paraffin fixed dermis and epidermis. Next, fibroblasts were stimulated with pro-inflammatory and/or pro-fibrotic cytokines such as TGF $\beta$, IL-1 $\beta,-4,-13,-17 \mathrm{~A}, \mathrm{TNF} \alpha$ and PDGF. In order to identify downstream effects of miR-125b, knockdown with anti-miR-125b (or scrambled controls) in HC fibroblasts was performed. RNA was isolated from healthy fibroblasts $(n=4)$ after knockdown and was proceeded to deep sequencing using Illumina HiSeq2000. Sequencing data were validated using $\mathrm{GPCR}$ on $\mathrm{HC}$ as well as SSc fibroblasts. Apoptosis was assessed by Caspase-Glo 3/7 assay and immunofluorescence of cleaved caspase 3 on cultured fibroblasts.

Results: Screening identified miR-125b as one of the candidate miRs differentially expressed in SSc. MiR-125b was confirmed by qPCR in primary dermal fibroblasts ( $\mathrm{SSc}=11, \mathrm{HC}=8$ ), where it was downregulated by $47 \%$ (median expression $53 \%, Q_{1,3} 33 \%, 70 \% ; p<0.01$ ). MiR-125b expression appeared to be independent from main cytokines operative in SSc. Additionally, the expression of miR-125b was assessed in skin biopsies of both SSc patients $(n=4)$ and $H C(n=5)$. In SSc, miR-125b was downregulated by $35 \%$ (median expression $65 \%, Q_{1,3} 61 \%$, $78 \% ; \mathrm{p}<0.05)$. To localize its expression in the skin, we separately analyzed miR-125b expression in dermis and epidermis of paraffin fixed skin. In both cases, expression of miR-125b was downregulated.

RNA sequencing identified $>3500$ differentially expressed genes with $p<0.05$. More than half of the differently expressed genes with at least $15 \%$ change were predicted targets of miR-125b by TargetScan and MiRWalk, indicating successful functional inhibition of miR-125b. Gene ontology revealed extracellular matrix organization and apoptosis regulation as the two main clusters of differentially expressed genes. Among them, BAK1, BMF and BBC3 are participants of the BCL2 apoptosis pathway and predicted targets of miR-125b. Consistent with the sequencing results, qPCR showed that knockdown of miR-125b upregulates these genes 24, 48 and 72 hours after transfection $(p<0.05$ for each). That was confirmed also on protein level by Western blot. Accordingly, miR-125b knockdown resulted in a higher rate of apoptosis (mean \pm SD: $60 \% \pm 29 \%, p<0.01$ ) compared to scrambled controls, measured by Caspase-Glo $3 / 7$ assay.

Moreover, miR-125b knockdown reduced TGF $\beta$-induced $\alpha$ SMA expression both on RNA and protein levels, suggesting that miR-125b might play an additional role in the cytoskeletal reorganization of fibroblasts during fibrosis.

Conclusions: MiR-125b is differentially expressed in SSc skin and primary dermal fibroblasts. MiR-125b downregulation increases apoptosis, inhibits cytoskeletal reorganization and therefore might become a potential anti-fibrotic therapeutic strategy.

Disclosure of Interest: A. Kozlova: None declared, E. Pachera: None declared, F. Renoux Grant/research support from: Swisslife, M. Rudnik: None declared, B. Maurer Shareholder of: Patent licensed: mir-29 for the treatment of systemic sclerosis, Grant/research support from: AbbVie, Protagen, EMDO, Novartis, Pfizer, Roche, Actelion, A. Jüngel: None declared, J. Distler Shareholder of: 4D Science, Grant/research support from: Anamar, Active Biotech, Array Biopharma, BMS, Bayer Pharma, Boehringer Ingelheim, Celgene, GSK, Novartis, Sanofi-Aventis, UCB, Consultant for: Actelion, Active Biotech, Anamar, Bayer Pharma, Boehringer Ingelheim, Celgene, Galapagos, GSK, Inventiva, JB Therapeutics, Medac, Pfizer, RuiYi, UCB, G. Kania Grant/research support from: Bayer, O. Distler Shareholder of: Patent licensed: mir-29 for the treatment of systemic sclerosis, Grant/research support from: Actelion, Bayer, Boehringer Ingelheim, Pfizer, Sanofi, Consultant for: 4 D Science, Actelion, Active Biotec, Bayer, Biogenldec, BMS, Boehringer Ingelheim, ChemomAb, EpiPharm, espeRare foundation, Genentech/Roche, GSK, Inventiva, Lilly, medac, Mepha, Medlmmune, Mitsubishi Tanabe Pharma, Pharmacyclics, Pfizer, Sanofi, Serodapharm, Sinoxa, Speakers bureau: AbbVie, iQone Healthcare, Mepha

DOI: 10.1136/annrheumdis-2017-eular.3806 